Studia z Dziejów Rosji i Europy Środkowo-Wschodniej. LVI (3)

$\begin{array}{lllllllll}\mathbf{A} & \mathrm{R} & \mathrm{T} & \mathrm{I} & \mathrm{C} & \mathrm{L} & \mathrm{E} & \mathrm{S}\end{array}$

Marek Rutkowski

https://orcid.org/0000-0001-9553-4790

University of Physical Education in Kraków

\title{
Russian-Prussian surrender of fugitives and deserters: cartel conventions of the 1840s and 1850s
}

Zarys treści: Artykuł analizuje ekstradycyjne konwencje kartelowe zawarte pomiędzy Rosją carską i Królestwem Prus w okresie lat czterdziestych i pięćdziesiątych XIX wieku. Przedstawiwszy realne uwarunkowania procedur wydawania zbiegów w Królestwie Polskim w okresie po upadku Powstania Listopadowego, kolejna część artykułu skupia się na dokładnej analizie rosyjsko-pruskiej umowy ekstradycyjnej z 8/20 maja 1844 roku. W dalszej kolejności poddano ocenie treść konwencji o wzajemnym wydawaniu dezerterów i zbiegów, sfinalizowanej w dniu 27 lipca / 8 sierpnia 1857 roku w imieniu cara Aleksandra II i króla pruskiego Fryderyka Wilhelma IV. Zakończenie uwypukla pewną powtarzalność szeregu rozwiązań prawnych zawartych w analizowanych umowach kartelowych, przy występowaniu jednak oczywistej weryfikacji ich zapisów, związanej z doświadczeniem praktycznym i założeniami intencjonalnymi.

Content outline: The article analyses the extradition cartel conventions concluded between Tsarist Russia and the Kingdom of Prussia during the 1840s and 1850s. The first part is devoted to the discussion of the actual conditions that affected the procedures for the release of fugitives in the Kingdom of Poland after the failure of the November Uprising. The second part offers an in-depth analysis of the Russian-Prussian extradition agreement of 8/20 May 1844 . Thirdly, the study examines the convention on the exchange of deserters and fugitives that was agreed upon on 27 July / 8 August 1857 on behalf of Tsar Alexander II and King Frederick William IV of Prussia. The conclusions draw attention to the repetitive character of a number of legal arrangements included in cartel conventions, but also emphasise that some provisions were subject to verification, depending on practical considerations and intentions.

Słowa kluczowe: Rosja, Prusy, ekstradycja, traktaty dwustronne, 19 wiek

Keywords: Russia, Prussia, extradition, bilateral treaties, nineteenth century 


\section{Introduction}

On 10 May 1863, the New York Times published a tellingly titled article: "PrussoRussian Extradition Treaties." It described the situation that arose at the border between the Russian Empire (and the Kingdom of Poland) and the Kingdom of Prussia after the outbreak of the January Uprising; its authors, overcome with indignation, wrote: "The recent instructions of the Prussian War Minister, to the Commanderin-Chief of the armies of King William [i.e. Wilhelm - M.R.] on the Russian frontier, touching the mode of proceeding against such fugitive Poles as shall be so infatuated as to flee into Prussia for safety, reveal the nature of those 'cartel conventions,' on the fulfilment of which the royal Brandenburgher just now lays so much stress.

Extradition treaties, binding the contracting parties to the reciprocal surrender of such criminals as may take refuge in the territory of either, have been entered into by most modern Governments; and where the real aim of those instruments is to promote the interests of justice and social order, they are quite proper. But such is not the aim of the 'cartel conventions' between Russia and Prussia. These conventions stipulate, indeed, for the surrender of felonious offenders, yet their main object is evidently to secure the surrender of political refugees - a class which in France, England, America, and almost everywhere, are exempt from the operation of extradition treaties.

The Prusso-Russian cartel conventions are, in fact, elaborately constructed traps for the capture of fugitive Polish patriots. Several conventions of this kind have, from time to time, been concluded between the Powers in question; but the glory of having inaugurated a systematic plan for their more effectual execution has been reserved for the reigning Prussian monarch and the Von Bismark Ministry.

To give a helping hand to the Czar in crushing the Poles was, doubtless, a labour of love for William [i.e. Wilhelm - M.R.] and his Cabinet; and well and thoroughly have they worked in furtherance of their object. All regard to national honour, all regard to justice and precedent, they have cast to the winds. The fugitives are to be classed with Aristotelian precision. In the first category are to be placed all who have taken part in the insurrection, or deserted from the Russian ranks. The second is to comprehend all who have fled from the conscription, or who may be liable to it hereafter. The third is to be composed of those who are neither political criminals nor subject to conscription - the very young, the very old, the infirm and the innocent.

Formerly arrests were only made on the requisition of certain Russian officials, and the observance of this rule gave the victims some chance of escape; but now that restriction is to be dispensed with, at least in the first instance, and the refugees are to be seized on wholesale the moment they set foot on Prussian soil. By what process the police of William [i.e. Wilhelm - M.R.] are to distinguish insurgents from deserters, and the guilty from the guiltless, in the absence of all evidence, is not very apparent. 
Save for the purposes of classification, however, this difficulty will not produce much inconvenience, since the mere fact of their being Poles will be a sufficient proof of their delinquency. After arrest, they are to be conducted to certain frontier fortresses, where they are to be confined, fed on prison fare, and kept at convict labour, till arrangements have been made for their surrender to the Czar, and the amount of groschens or kopecks which their support may have cost has been paid to the Prussian monarch."1

Thus reported the evidently pro-Polish New York daily, whose authors could not tolerate the fact that the Prussians and Russians used extradition procedures for strictly political purposes during the January Uprising.

Granted, the post-1863 situation and its unique character require proper understanding, but (even without considering the overall coverage of the extraordinary period of the January Uprising by that American newspaper) I would like to focus instead on the legal and practical aspects of extradition in the relations between Russia and Prussia in the mid-nineteenth century, paying particular attention to the two decades that preceded the uprising. This is because the new law- and state-related considerations concerning extradition that date back to the 1840 s and 1850 s provided an opportunity for settling a number of sensitive issues that arose between the Russian Empire (and the Kingdom of Poland) and the Kingdom of Prussia. There can be no doubt that among those were the ever-present border issues, notably that of deserters and fugitives; this refers not only to soldiers who defected from military service, but also conscripts (or those who feared being drafted yet another time) and, obviously, ordinary criminals trying to escape justice.

Evidently, it was all these issues, about which the two states were naturally and equally concerned, that led to the conclusion of those two Prusso-Russian cartel agreements within the aforementioned time frame. The intention behind this arrangement was if not to eliminate, then at least to significantly reduce the number of deserters and fugitives.

The present article, therefore, aims to offer a detailed discussion of the RussoPrussian regulations of the 1840 s and 1850s concerning prevention of illegal border crossings that were made with a view to taking refuge in the territory of the other state. Consequently, the article first discusses the foundations of the extradition regime in the Kingdom of Poland after the fall of the November Uprising, and then provides a detailed analysis of those two Russo-Prussian legal arrangements from the period delimited by the two Polish insurrections, i.e. a) the cartel agreement of $8 / 20$ May 1844; b) the convention of 27 July / 8 August 1857 . The analysis of the content of these two agreements concluded between Russia (but also Poland, at least theoretically) and Prussia, will often lead to a factual recapitulation

\footnotetext{
1 "Prussian-Russian Extradition Treaties," New York Times (10 May 1863), p. 4, https://www. nytimes.com/1863/05/10/archives/prussorussian-extradition-treaties.html (accessed: 4 October 2020).
} 
of data; this should make it possible to produce a detailed picture of the attempts at solidifying the legal measures aimed at effective capture and exchange of deserters and fugitives by the two states, an undertaking guided by the principle of "peaceful existence."

The issue of extradition in the relations between Russia and Prussia has already been discussed in scholarly literature. In this regard, of particular worth are such studies as The Practice of Extradition from Antiquity to Modern France and the United States: A Brief History by Christopher L. Blakesle, ${ }^{2}$ The Development of the Conceptual Frame Work Supporting International Extradition by Valerie C. Epps ${ }^{3}$ and The Domestic Politics of International Extradition by William Magnuson. ${ }^{4}$ As to studies written in Polish, the book by Krzysztof Latawiec titled Rosyjska straż graniczna $w$ Królestwie Polskim w latach 1851-1914 [Russian Border Guards in the Kingdom of Poland in the Years 1851-1914], ${ }^{5}$ which undoubtedly refers to the topic under discussion, is also worth mentioning.

The article is mainly based on the sources published in Polnoe sobranye zakonov Rosijskoj Imperii and Gazeta Rządowa Królestwa Polskiego, as well as on biographical information.

\section{Practical grounds for the functioning of the extradition system between the partitioning states on the territory of the Kingdom of Poland established at the beginning of the Paskevich period}

The organisational and legal basis for the functioning of extradition between the partitioning states obviously manifested itself in the most important area in this regard, namely, in the territory of the Kingdom of Poland. Developed under different political realities resulting from the suppression of the November Uprising, the basis in question laid the groundwork for the subsequent Russo-Prussian "clarifications concerning capture of fugitives" of the 1840s and 1850s.

In the spring of 1832, on the orders of Field Marshal Ivan Paskevich, "post stations for the exchange of fugitives were re-established [in the Kingdom of Poland]." Originally, three such exchange stations were established on the border between the

2 Ch.L. Blakesle, "The Practice of Extradition from Antiquity to Modern France and the United States: A Brief History," Boston College International and Comparative Law Review, 4/1 (1981), pp. 39-60.

3 V.C. Epps, "The Development of the Conceptual Frame Work Supporting International Extradition," Loyola of Los Angeles International and Comparative Law Review, 25/3 (2003), pp. 369-388.

${ }^{4}$ W. Magnuson, "The Domestic Politics of International Extradition," Virginia Journal of International Law, 52 (2012), pp. 839-901, where the author in footnote 42 on p. 848 refers to the related arrangements between Russia, Austria and Prussia.

${ }^{5}$ K. Latawiec, Rosyjska straż graniczna w Królestwie Polskim w latach 1851-1914, Lublin, 2014. 
Kingdom of Poland and Prussia, each on the side of the former: a) in Szczuczyn in the Augustów Province; b) in Dobrzyń on the Drwęca River in the Płock Province; and c) in Kalisz in the Kalisz Province. They were placed under the management of the Government Commission for Internal Affairs with its seat in Warsaw, which was obliged to provide funds for the upkeep of the stations. It was the duty of the officers in charge of the respective stations to send detailed reports "on the progress and developments that had occurred within their remit" to Warsaw every ten days, along with registers and charts. In addition, each station had to submit their accounts for inspection to the Government Commission for Internal Affairs every three months so that the validity of their actions could be properly assessed. ${ }^{6}$

Moreover, at about the same time (i.e. soon after the suppression of the November Uprising), Field Marshal Paskevich ordered that "instructions for officers tasked with the exchange of fugitives at border stations" should be drafted and made mandatory. The preamble to those instructions stated that Paskevich had personally ordered the establishment of four "stations for the exchange of fugitives" on the borders of the Kingdom of Poland (the fourth was located on the border with Austria). Each station was staffed by a cohort of veterans, or Cossacks, whose main task was to escort fugitives. In all cases, the "extradition service" at every station was entrusted to a veteran officer, who was to perform his duties temporarily under the supervision of a serving officer: the former was required to set the general framework of the tasks and duties to be performed by the station, while the latter was responsible for overall supervision of the station to which he had been assigned. As a result, the two officers had to maintain their checks and balances, especially as all the reports and official correspondence of the station had to be signed by both. ${ }^{7}$ It is worth noting, therefore, that extradition-related matters after September 1831 were entrusted not only to Russian officers, but also to ex-officers of the disbanded Polish Army. ${ }^{8}$

The instruction was composed of seventeen articles, the first of which indicated that the extradition stations located on the Prussian border were required to proceed with the handover of fugitives from the Prussian and Austrian armies (and of the recruits who had gone into hiding) in keeping with the provisions of the cartel convention of 17/29 March 1830. ${ }^{9}$ By contrast, the extradition station on the Austrian border (in Tomaszów) was to comply in this respect with the provisions of the convention of 5/17 June 1815 and with its supplementary articles that were agreed upon on 14/26 July 1822.

${ }^{6}$ Dziennik Urzędowy Województwa Mazowieckiego, 37 (4 June 1832), p. 685.

7 Central Archives of Historical Records in Warsaw (AGAD), Zespół II Rady Stanu Królestwa Polskiego 1833-1841 (hereafter: II RS), call no. 102/62.

${ }^{8}$ II RS, call no. 103/48-50.

9 On 17/29 March 1830, i.e. before the outbreak of the November Uprising, Russia and Prussia renewed the previously concluded cartel convention concerning the exchange of fugitives from the military and criminals. It is worth noting that this convention was actually implemented in 1832 . 
The procedure concerning the initial stage of capture of fugitives was described in Article 2 of the instruction. It stated that immediately after the given fugitive was apprehended in the territory of a particular commune, it was the duty of the local chief official to draw up a protocol based on verbal statements, "illustrating the actual process of the deserter's capture." The protocol was to include: a) the name and surname of the apprehended person; b) place of birth; c) the name of the military unit to which the captured fugitive was assigned (if applicable); d) the date and place of escape; e) description of the apprehended person's clothing; f) a list of the equipment and weaponry that had been found on them; g) description of the fugitive's horse, if captured, and, optionally, h) the name of the person authorised to receive the reward (taglia, provided for in the cartel conventions) for having provided information that made the capture possible.

Subsequently, the chief official of the commune was to hand over the detainee and all the items found on him (along with the horse, if it had been caught) to the office of the district commissioner. The protocol based on his verbal statement had to be handed over as well in order to make it possible for the district commissioner to check and verify the case in question.

It follows from the above that it was the commissioner's formal duty to qualify such individuals as fugitives. After verification, the district commissioner reimbursed the chief official the costs of the deserter's keep, calculated depending on the border (Prussian or Austrian) where the detention took place. ${ }^{10}$ Thus, for the extradition stations situated at the Prussian border, these amounts were calculated in accordance with Articles 11 and 12 of the Russo-Prussian cartel convention on fugitives, whereas the respective calculations for the stations on the Austrian border were done in accordance with Articles 6, 7, 8 and 9 of the Austro-Russian cartel convention. The district commissioner taking over the fugitive was also obliged to pay a cash reward (taglia) to the person who had informed the authorities on the captured individual.

Once all the formalities were completed, the district commissioner was to send the fugitive (along with the aforementioned protocol, his belongings and, if applicable, his horse) immediately to the nearest extradition station. The transfer was done under the guard of veterans or Cossacks, who also received funds sufficient for the fugitive's keep. The amount was calculated from the day of departure to the day of arrival at the proper extradition station at a rate of fifteen Polish groschen per day. Once the fugitive had been transferred to the required destination, the station had to confirm the handover and reimburse the district commissioner the cost of transfer and of the captive's keep.

The extradition station was then obliged to draw up a "personal file" of the fugitive, which was to be completed without delay and report the current state of affairs concerning the apprehended person. It had to include an inventory of the

${ }^{10}$ Dziennik Urzędowy Województwa Mazowieckiego, 37 (4 June 1832), p. 684. 
requisitioned items, along with the sum total of the costs incurred and the amount of the reward for his capture, all of which was to be paid back to the respective district commissioner. Once the fugitive and his documentation had been handed over to the adjacent extradition station of the other state, the latter institution was obliged to pay all these sums to the party that surrendered the captured person. According to Article 8 of the instruction approved by Field Marshal Paskevich, "remuneration for the capture of the fugitive and the costs of his keep" had to be specified with particular precision; all this was to be clearly stated in the receipt issued by the extradition station of the other party.

Article 9 of the instruction stated that the extradition stations were obliged to take over Russian and Polish fugitives surrendered by the Austrian and Prussian authorities "along with those who went into hiding to avoid conscription." Another obligation of the extradition stations was to reimburse the costs of the transfer and upkeep of apprehended deserters.

The routes along which the deserters were to be escorted to the border and handed over to the military authorities were also precisely specified (Article 10). The following destinations were indicated: Zamość (for the extradition station in Tomaszów on the Austrian border), Łomża (for the station in Szczuczyn) and Płock (for the station in Dobrzyń).

All the stations had to keep their own accounts, so that the amounts paid and received there could be recorded "with the greatest possible accuracy." In order to facilitate the keeping of accounts by the staff of the stations, one of the officers assigned to the given station was obliged to visit its counterpart in the other country (i.e. Austria or Prussia) every three months, mainly in order to verify the accounts with the officer in charge of that station. Such visits were also intended to clarify "all doubts that might arise in relation to extradition service."

In addition, each extradition station in the Kingdom of Poland was to keep two registers: one was to record the fugitives surrendered to the other state, while the other recorded the incoming fugitives who were handed over by the commanding officer of the other party. It comes as no surprise that the "extradition officers," burdened as they were with numerous daily duties, were required to remain in service without leaving the station's premises, unless the superior authorities granted them permission to do so, or they managed to find other officers to stand in for themselves. However, exceptions to this rule were permissible, particularly when such officers had to "attend places designated for the exchange of fugitives." 11

Following the establishment of the legal and organisational framework for extradition-related activities in the Kingdom of Poland that was agreed upon between the Kingdom of Poland, the Austrian Empire and the Kingdom of Prussia in 1832 (there were no such stations on the Polish-Russian border, as the Kingdom of Poland formed part of the Romanov Empire), two more exchange stations were

11 Dziennik Urzędowy Województwa Mazowieckiego, 37 (4 June 1832), pp. 685-686. 
set up on the Polish-Austrian border (as of 1836): one in Tomaszów, and the other in Wilczkowice. ${ }^{12}$ This state of affairs remained in place until the late $1830 \mathrm{~s}^{13}$

As far as extradition relations with Prussia are concerned, there were several exchange stations within the Kingdom of Poland on its border with Prussia in the mid-1830s: Wierzbołów, Szczuczyn, Kalisz and Dobrzyń on the Drwęca. ${ }^{14}$ Also in the late 1830s (as of 1838), the exchange of fugitives on the Polish-Prussian border continued in the following extradition stations established within the boundaries of the Kingdom of Poland: Dobrzyń on the Drwęca, Wieruszów, Szczuczyn and Kalisz. ${ }^{15}$

It should be noted that for both the Prussian and Austrian borders, the reports of the Government Commission for Internal, Religious and Educational Affairs make no direct reference to the number of "military fugitives."16

As early as in 1837, a problematic issue emerged in regard to extradition relations with Prussia, when (as evidenced in a report by the aforementioned government commission) "experience has taught us that some individuals who were liable for conscription took refuge in such places." 17 This must have been disturbing for the partitioning states and may have additionally stimulated further developments in Russo-Prussian relations concerning the legal framework that referred to extradition-related issues.

\section{The Russo-Prussian cartel agreement on extradition of 8/20 May 1844}

The cartel agreement on the rendition of fugitives and deserters, which was in force for much of the Paskevich period in the Kingdom of Poland conquered by the Russians after the war of 1831, was signed between Russia and Prussia on $17 / 29$ March 1830. It expired in the early 1840s; moreover, in the meantime it had become apparent that some articles of the original agreement "required further elaboration and greater clarity," while others, as a result of changes in the social, political and economic situation, were no longer in line with the relevant circumstances. As a consequence, as stated by Tsar Nicholas I in the preamble to the new extradition convention concluded between Russia and Prussia on 8/20 May

12 II RS, call no. 104/214.

13 II RS, call no. 105/107.

${ }^{14}$ II RS, call no. $104 / 214$.

15 II RS, call no. 105/107.

16 II RS, call no. 103/48-50.

17 II RS, call no. 105/5. According to the report of the government commission, this situation met with active ministerial counteraction, when it was decided, after numerous Russo-Polish-Prussian consultations, that in cases where such fugitives were caught, proper testimony protocols had to be drawn up. These protocols then provided a legal basis "for further consideration." 
1844, the newly introduced version of the cartel agreement on the surrender of deserters and fugitives was signed "by mutual agreement" between the monarchs of the two countries. Prominent representatives of Prussian and Russian diplomacy took part both in the negotiations themselves and in drafting the final version of this bilateral agreement. On the Russian side, it was Count Petr Kazimirovich Meyendorff, ${ }^{18}$ the Tsar's privy counsellor and chamberlain, who at the same time performed the duties of Russian special envoy and minister plenipotentiary to the Prussian King and the Grand Duke of Mecklenburg-Schwerin. He held numerous distinctions, including grand crosses of several orders that were then under the decree of Tsar Nicholas I (a second-class Order of St. Vladimir; a first- and fourth-class Order of St. Anne, a White Eagle, a first-class Order of St. Stanislaus; and the Prussian Order of the Red Eagle with diamonds). In these negotiations, Prussia was represented by Baron Heinrich Urlich Wilhelm von Bülow, ${ }^{19}$ who was then Berlin Cabinet Minister and Minister of Foreign Affairs. He also held many distinctions, including the Grand Cross of the Prussian Red Eagle and a few of the Tsar's orders: St. Alexander Nevsky, a first-class Order of St. Anne, a fourthclass Order of St. Vladimir, and a second-class Order of St. Stanislaus with Star. He was also a Chevalier of the Grand Cross of the Austrian Order of Leopold. In addition, Bülow also held a number of distinctions from other countries, including the Bavarian Order of Civil Merit, the Hanoverian Order of the Guelphs, the Order of Louis the Great form the Duchy of Hesse, the Saxon Order of the White Falcon, the Grand Cross of the Lion of the Netherlands, the Order of Leopold of Belgium and the Grand Order of Nichani Ifichar from Turkey. ${ }^{20}$

The two diplomats signed the Prusso-Russian extradition convention "having exchanged their plenipotentiary powers and having confirmed that they were formulated properly." The date for the new law to enter into force was set at four weeks after the mutual exchange of ratification documents. The convention was intended to remain valid for twelve years, and its provisions were also to apply to the authorities of the Kingdom of Poland.

The issue of the ratification was resolved in such a way that the signed and duly certified documents were to be exchanged within six weeks, or, should this prove possible, at an earlier date in Berlin, but it so happened that Tsar Nicholas I ratified the new convention at Tsarskoye Selo on 10/22 June $1844 .^{21}$

18 "Bar. Meyendorff Pietr Kazimirowitch," in: Spisok grazdanskim chinam piervych III klassov, Ispr po 1-je jnv. 1863 2., Sankt-Petersburg, [1863], pp. 29-30; https://vivaldi.nlr.ru/ab000000479/ view/?\#page $=49$ (accessed: 23 December 2020).

19 A. Ritthaler, "Bülow, Heinrich Ulrich Wilhelm Freiherr von," in: Neue Deutsche Bibliographie, 2 (1955), https://www.deutsche-biographie.de/sfz35397.html\#ndbcontent (accessed: 17 August 2020).

20 Gazeta Rządowa Królestwa Polskiego, 166 (15/27 July 1844), p. 1189.

${ }^{21}$ Gazeta Rządowa Królestwa Polskiego, 167 (16/28 July 1844), p. 1200. 
As a matter of principle, and in line with the wording of Article 1, the convention referred to three basic categories of persons and objects. The first of these referred to all deserters evading their obligation of active military service and to all objects (clothes, uniforms, etc.) that they had taken with them during their escape, including horses that belonged to the army. This group also included those who, having been formally discharged from the army, were obliged to return to active service whenever called upon; for this reason, they were considered members of the military reserve. The second group included those individuals who were liable to conscription, but broke the law of the given state by illegally crossing the border (regardless of whether they intended to return). The final category included those who "have committed a crime in whichever of the two powers," fleeing the territory of their state "in order to escape justice and the deserved punishment."

If a fugitive was caught wearing a uniform and found to be carrying other objects or things that traditionally belonged to the military equipment (which, in general, would clearly indicate that the fugitive in question served in the army of the given party to the convention), then, in keeping with Article 1 of the agreement, such person was to be escorted "to the border separating the two states" and handed over "immediately" to the relevant and competent authorities. In the case of individuals whose escape from one of the two states was not self-evident (in the original version: "patent"), but became probable over the course of the inquiry that was based either on their own statements or on a detailed examination of the circumstances, the military or civil authorities of the receiving state were obliged to determine precisely the whereabouts of that person from the moment when they had crossed the border and to take all measures to prevent them from escaping any further. The party receiving the alleged fugitive/ deserter would then make a record of his testimony ("a verbal account"), which was subsequently shared with the local military authorities of the other party. It was up to the latter to decide whether the apprehended individual was in fact a fugitive. If this was the case, the person in question was to be handed over to the representatives of the military of the other party. By contrast, individuals who crossed the border illegally but did not appear to have escaped from the military (at least not conspicuously) were not automatically detained and handed over to the other country unless the authorities of the country of origin specifically requested it.

Article 3 of the agreement of 20 May 1844, however, indicated certain conditions preventing the deportation of evident and presumed fugitives and deserters. Namely, such deportation could not take place if: a) the country to which they illegally crossed the border, i.e. where they were caught, was the country of which they were citizens at the moment of their illegal crossing of the border; $b$ ) if the legal conditions in which those fugitives/deserters found themselves "were not abolished in accordance with the forms prescribed by the laws of that power [=the relevant country of which they were citizens - M.R.]." 
Regardless of whether fugitives were handed over as subjects of the given state or not, the horses and military "utensilia" (including the uniform) that they had taken with themselves when crossing the border had to be handed over as well. Similarly, if a fugitive/deserter committed a serious offence in the country of his new residence, his surrender could be refused until he had fully served the sentence imposed by a competent court of law. However, the apprehension and surrender of a fugitive could only be effected by means of a summons issued by the authorities of the party from which the person had fled (in principle, this refers to individuals whose status of military deserters was uncertain), the statute of limitations came into play, since such persons could only be surrendered within two years of the date on which they had escaped. After that, the legal obligation to surrender such a deserter expired.

According to Article 4 of the agreement of May 1844, the parties to this agreement were to exchange opinions and general correspondence regarding persons suspected of "escaping from [military] service" in such a way that the documentation received from the administration of the Russian Empire and the Kingdom of Poland was to be directed to the commanding general of the nearest Prussian province. The Prussians, in turn, had to contact the Russian "[local] commander-in-chief and the officers appointed to hand over the fugitives." Summonses regarding persons who did not belong to the category of blatant deserters were, as a rule, sent by the Russian (and Polish) side to the nearest Prussian provincial regency; on the Prussian side, such summonses were submitted to the chiefs of the nearest Russian military and civil administration offices (only civil in the case of Poland, of course).

The procedure was different in the case of catching "repeat" military fugitives. If it turned out that a given individual, before escaping from the army of one or the other of the parties to the convention, had already fled from the army belonging to a third monarch/government with which Russia or Prussia had concluded a separate cartel convention, then such a fugitive was to be "returned to the army" that he "had abandoned most recently." 22

With regard to both military and civil authorities, the convention of 1844 expressly prohibited admission into the military service of anyone whose escape from the army of the other party was not only beyond all doubt, but also in cases where it was only probable. Nor was it permissible to any officer or rank and file soldier from a given party to cross the border unless he was in possession of a passport, or at least a document certifying formal discharge from service granted by the commander of his corps or by some other person in charge of that corps at the time.

There was even a possibility of meting out "preventive punishment" and reporting on cases of "alleged" illegal border crossings by military personnel. Anyone

22 Gazeta Rządowa Królestwa Polskiego, 166 (15/27 July 1844), pp. 1190-1191. 
unable to produce a valid passport or discharge from service and apprehended by (or reported to) the competent authorities while intending to cross the border illegally, "whose appearance or other circumstances made him suspect of being a soldier in the service of the other state," was to be immediately detained (the same applied to all his belongings). This was to be followed by investigation, the proceedings of which were duly recorded in protocols that may have been handed over to the other state.

According to the convention of 20 May 1844, both parties had to make every effort to ensure that requests to official bodies for the surrender of fugitives were made promptly and fairly. Even in cases where a person wanted on suspicion of escape had in the meantime joined the army or the civil administration of the country of refuge, this solution did not in principle have any influence on the further course of extradition proceedings. In accordance with Article 8 of the convention, if doubts arose as to the truthfulness/reliability of the description of the "circumstances" presented as evidence in the extradition request, it was not admissible to refuse the surrender of a particular fugitive on these grounds (there were a few exceptions, however, laid down in Article 3).

When deserters (or any other person formally liable to military service, including in the future) were handed over to the other party, the procedure of their surrender was always to be accompanied, with no exceptions whatsoever, by submitting an interrogation report (known as "verbal testimony") that was drawn up "in order to determine the reasons for the detention and all other circumstances of the case." Moreover, if the detainees belonged to the category of individuals who were to be handed over automatically (this applied especially to deserters from the military), the "military utensilia" found on them had to be returned immediately together with the detainees, especially those that had helped to track down the deserter in question. However, if the person to be surrendered could only be deported on the grounds of a bilateral agreement between the military authorities, or following a specific individual request made by the other party, then, with a view to eliminating all possible concerns as to the legitimacy of the surrender of a particular individual (in the light of the convention of 20 May 1844), the extradition request itself was to be presented at the time of the actual surrender of the fugitive (in the original form or as a certified copy).

Another important feature of the new convention was stipulated in Article 10, which confirmed the selection of previously established border stations that were to serve as points of exchange where fugitives and other extradited persons were to be handed over and received. However, a proviso was added concerning the location and number of the relevant extradition stations: it stated that the existing stations could be shifted to other places and that new ones could be set up, depending on the renewed bilateral agreements on increasing the number of extradition stations. At the same time, each party to the convention was free to select the officials appointed to receive extradited persons: they could be appointed by military 
or civil authorities, depending on the laws and administrative and organisational structures of the given state, which means that those posts could be filled by civil and military personnel alike.

The living expenses of the apprehended illegal border crossers were calculated in 1844 as follows: for each fugitive or person in active military service, the daily allowance was: a) on the Russian side - seven and a half silver kopecks, b) on the Prussian side - two and a half silver groschen. The accrual of these sums began directly from the day of detention, made for the purpose of expelling the apprehended individual, whether ex officio or at the summons of the opposite party. In the case of the abduction of a service horse by a fugitive, its daily board (calculated from the same point as in the case of the fugitive) consisted of: a) two "pots" of oats; b) eight pounds of hay and c) the necessary amount of straw. Fodder expenses were calculated unevenly, according to the current price at a given moment, with the rates in force in the nearest town as the basis for the calculation.

According to the rules in force at the time (which were basically unchanged compared to the previously established ones, at least in terms of timeframes), the fugitive had to be handed over within eight days of his apprehension at the latest, which had to be done "as soon as the fugitive is discovered." In 1844, the principle was introduced of a joint and equal (i.e. 50/50) payment of the costs of his forced detention within eight days. An exception was made for cases in which the formally established duration of the fugitive's detention had to be extended, either because the place where the deserter was apprehended was a long way from the national border or due to "other sufficiently favourable circumstances." In cases where the detained deserter/fugitive fell ill and had to be hospitalized, the costs of his treatment fell on the party demanding the surrender of the fugitive. The rate here was ten and a half kopecks in silver, or three and a half Prussian groschen in silver per day, and was calculated for the entire period of hospitalization. The above-mentioned costs of living could not be increased beyond the stipulated amount. ${ }^{23}$

According to Article 12 of the convention, due to the capture of not only the fugitive but also the "service horse" on which the fugitive was riding, the horse had to be "handed over to the country to which it belongs." The person who reported the case was to be rewarded by the authorities of the country to which the animal would be handed over in the amount of six roubles seventy kopecks in silver, or seven and a half silver Prussian thalers.

In order to streamline the process of paying such rewards as quickly as possible, and to cover the costs of keeping the deserters apprehended, the Russian-Polish and Prussian authorities entrusted "a certain amount of money" to the management of officials located at the border stations and assigned to "receive" the deserters. This money was supposed to cover the costs of settling the accounts for the handing

${ }^{23}$ Gazeta Rządowa Królestwa Polskiego, 166 (15/27 July 1844), pp. 1191-1192. 
over of deserters, etc. The accounts were such that upon the apprehension of a military deserter, an ordinary fugitive or animals belonging to them the border officials were obliged to: a) pay the costs of their upkeep and, if applicable, b) reward the captors of the horse. The sums in question were paid on the basis of bills presented by officials of the country from whose territory the surrender was to take place. The legislator even foresaw the possibility of discrepancies in the bills, noting, however, that this was unlikely, as "the price, maintenance expenses and remuneration are clearly indicated." In any case, even incorrect bills had to be paid, with the option of later verifying the facts.

There were certain exceptions to these rules of payment of bounties, issuance of minutes, etc. Neither the reward nor the maintenance payment was made when: a) "the state property found on him" was not handed over with the fugitive; b) neither the original record (the so-called "first copy") nor its certified copy contained a request for the return of the sums spent on keeping the fugitive, or possibly also his horse.

The debts incurred by civilian fugitives and military deserters during their stay in the country of flight could not, according to Article 14 of the 1844 Convention, be examined and taken into account by the authorities of the country of stay when handing over the fugitive to the other party. The reason, of course, was that fugitives could not incur debts "which the country to which they belonged was legally obliged to pay." If, on the other hand, the fugitive had incurred debts with private individuals during his stay in the state which had decided to extradite him, and then, because of his deportation, was unable to pay them, the person who had "claims" was entitled to address his complaint to the competent authorities of the fugitive's country of origin. On the other hand, military deserters or civilian fugitives had to be surrendered without delay, even if they were in custody at the time of the request for their deportation on account of unpaid financial obligations to private persons. ${ }^{24}$

Persons who had committed a criminal offence in one of the two signatory states, or at least had been accused of committing a serious offence, and then fled into the territory of the other state (or even just travelled lawfully; in this sense the convention also applied to persons formally crossing a border) were to be handed over to the other party on the basis of Articles 15 and 16 of the cartel agreement of 20 May 1844.

Belonging to a particular social status, or the so-called "birth" (i.e. nobility) of the person guilty or merely accused of a particular crime, could not have the slightest influence on the above regulation. Hence, the alleged criminal or offender should (and in fact had to) always be handed over to the demanders, completely regardless of his social status or birth, and this "regardless of whether he is a nobleman, an inhabitant of a town or village; a free man, a serf, a military

${ }^{24}$ Gazeta Rządowa Królestwa Polskiego, 166 (15/27 July 1844), p. 1192. 
man, or a civilian." The legislator also took into account the situation when an alleged criminal (or a person who was still only under indictment for the crime in question) was a citizen of the country to which he had just "taken refuge" after having committed the crime. In such a case, the fugitive in question was not handed over to the requesting party, but the authorities of the country of which he was a subject were obliged to order that he be administered "swift and strict justice," which was done according to the law in force at the place of trial. However, when a criminal was detained in a country where he had actually committed a crime, or just any "misdemeanour," the authorities of the country where the person was effectively detained were obliged to bring him to justice and subject him to appropriate punishment, which took place "even if the accomplice was a subject of another ruler."

Article 16 of the cartel convention of 20 May 1844 unambiguously stated that the possible detention of an individual scheduled for rendition from one country to another could and should take place at the express request of the police authority or court of the country where the alleged offender was likely to have committed the offence. In order for the procedure for such detention to be carried out properly and expeditiously, the relevant request for detention had to be served on the police authority or court of the other country. Those authorities and offices of the other party to whom the summonses or letters requesting detention were addressed, "even if they were not competent to comply with the summons received," had to receive the incoming requests in order to be able to forward them to the competent authorities for proper handling.

The legislator made it clear that in the case of the Russian Empire and the Kingdom of Poland, the actual surrender of the requested offender could take place "not earlier" than when the requirement for such a request to be made by the court of that Prussian province where the accused "had already been, or should be, brought to justice" was fully met. ${ }^{25}$ Similar rendition requests from the Prussian side were to be considered by the higher courts of the gubernias (in the original: "provinces") of the Kingdom of Poland, or the general governors of the gubernias (in the original: "provinces") of the Russian Empire, or any other place "where the offender was believed to have sought refuge." Both parties to the convention guaranteed each other (specifically, the Prussian and Polish kingdoms) to submit to the other country a complete list of higher courts authorised to apply for the surrender of fleeing criminals.

Regardless of whether the demand for the surrender of the fugitive was submitted to the Prussian side by the Russian governor-general or by one of the higher courts of the Kingdom of Poland, the covering letter had to be accompanied by: a) an excerpt from the sentence (if one had already been passed), or b) an excerpt from the so-called qualification decision, which should include in detail the

25 Gazeta Rządowa Królestwa Polskiego, 167 (16/28 July 1844), p. 1197. 
circumstances of the crime committed. The sentence and the qualification decision should have included a detailed description of the circumstances under which the prosecuted offence had been committed.

Applications for the surrender of an offender hiding in the territory of the other state (accompanied by supporting legal evidence) were to be submitted within a period of six months, counting from the date on which the notification of the actual detention of the offender (or only the suspected offender) was sent back to the office or court requesting such detention. Exceeding this deadline automatically resulted in the disappearance of the legal obligation to hand over the wanted criminal to the other party to the cartel convention.

According to the provisions of the 1844 convention, a de facto surrender could only take place if, following an "examination" of the suspect, the correct identity of the person being questioned could be established beyond doubt. The second necessary prerequisite for the surrender of such an offender was the appropriate classification of the act attributed to him, when the specific offence was considered to be subject to criminal procedure (according to the legal status of the country requesting deportation). The physical surrender of a fugitive offender took place in such a way that he was led under guard to the state border, where he was then handed over to the authorities of the requesting state (after the escorting guards had received relevant confirmation in writing).

The surrender of the criminal also entailed the payment of a number of fees. These concerned the payment of: a) the total costs of keeping the fugitive, calculated from the day of apprehension, at the rate of seven and a half silver kopecks, or two and a half Prussian silver groschen per day; b) the full costs of "confinement" (or detention) of the apprehended individual, calculated at nine and three quarters silver kopecks, or three and a quarter Prussian groschen in silver per day. In addition to this, it was also mandatory to reimburse: a) the one-off expenses incurred by taking the criminal to the state border, and $b$ ) the amounts due for the clothes provided to the prisoner. All these sums were to be "stated in separate bills for each particular case."

Just as the agreements of 1816 and 1830 had secured this in the past, the illegal crossing of the border by a military deserter or a civilian fugitive at least offered him security from physical prosecution by the services of the country from which he had fled. According to Article 18 of the cartel convention of 1844, neither a military fugitive nor any person liable (even in the future) to active service in the army, nor common criminals, could be pursued abroad in the possessions of the other country by the services of the prosecuting state "demanding surrender, be it violently, arbitrarily or clandestinely." Hence, in May 1844, it was pronounced unequivocally illegal to cross the Prussian border with the Russian Empire and the Kingdom of Poland by any Prussian or Russian "military or civilian detachment" or any secret envoy in order to capture a fugitive. Thus, even when there was a clear order from the pursuing state to catch one or more fugitives, mili- 
tary deserters, or common criminals, or "fugitive felons," and this action was to be carried out by either (a) a military detachment; or (b) a group of civilians; or alternatively (c) when the pursuit was ordered to be carried out "in some other way," such pursuit could go no further than to the border separating the two states. As already specified in previous conventions, upon reaching the border, the pursuing detachment had to stop at the border itself, and only one of its members could cross the border. However, the powers of such an emissary were severely limited, as "he was not allowed to commit any misdemeanour or lawlessness." In addition, the agreement of 20 May 1844 specified that the designated emissary's duty was only to go to the border office of the other state (i.e. to the local military or civilian official) to present a summons signed by his superior for the surrender of the fugitive (or fugitives). The envoy of the pursuing group was, as a rule, to be received with the considerations "which the two governments mutually owed to each other," and further proceedings in the specific case were conducted according to the provisions of the renewed convention.

Another absolute principle was the clear condemnation of any acts considered "lawless" and committed by military or civilian officials of one state in the territory of another sovereign. Acts committed without the express authorisation of the competent civilian or military officials of the host state were regarded lawless. Such lawlessness was qualified as "an offence against possessions" and was subject to appropriate penalties.

In the event of doubts as to whether the territory of the other state had been violated (literally "in respect of the offence against possessions") or as to any other "special circumstances" behind such "violations," a special joint commission had to be appointed, chaired by the commissioner designated by the injured party. At the same time, permanent commissioners were appointed to deal with border disputes. The following were appointed for this purpose: a) from the Russian side - commissioners located on the border of the Russian Empire with Prussia, and on the border of the Kingdom of Poland with Prussia, and "appointed [there] to watch over the maintenance of good neighbourly relations"; b) from the Prussian side - the provincial district councillors of those districts where the border had been violated. It should also be noted that the two parties to the agreement retained the right, in special cases, to entrust such investigations to so-called "separate officials." 26

The commissioners examining cases of border infringements were given powers to appoint, in special circumstances, a judicial officer to the bodies they presided over, in whose presence a witness had to be examined and sworn. The purpose of appointing the commission of this kind was to "thoroughly explain the deeds" by which was meant to analyse any actual violation of the possessions of a party signatory to the convention, and to identify the culprits. With the mutual agreement

${ }^{26}$ Gazeta Rządowa Królestwa Polskiego, 167 (16/28 July 1844), pp. 1198-1199. 
of the two commissioners of the given committee, the file of the trial had to be sent to the competent court of the country to which the culprit was subject in order to impose an appropriate formal penalty on the culprit(s). The penalty level adopted by the commission was also immediately notified to the authorities of the country where the principle of territorial integrity had been violated.

Any person detained on the territory of the country where they had violated the principle of territorial integrity was brought before the courts of that country. There was also a simple distinction in procedure: a) a military person was brought before a military court; b) a civilian was brought before a civilian court. Regardless of which court it was, its main duties in a given case were: a) to analyse the forbidden act itself (in a way, the whole procedure stemmed from the need for prosecuting the act); b) to examine witnesses and c) to clarify the whole matter "so that a sentence could be passed." Subsequently, in order to enable a sentence to be handed down in accordance with the domestic law of one of the signatory parties to the convention, the file was sent for inspection and analysis to the commander-in-chief of the army to which the offender belonged, or, in the case of civilians, to the civil administration of the state concerned. This stage of the procedure was to take place "without interruption and be completed as quickly as possible." If additional information and explanations of a supplementary nature were still required by the court assigned with pronouncing the final sentence, relevant arguments and explanations were to be provided at its request by the commissioners "authorised to examine the offence."

The cartel convention of 20 May 1844 prohibited the provision of effective assistance in escape by the party in whose territory the fugitive had fled. Article 20 of the convention strictly forbade officials and citizens of such states to "harbour" civilian fugitives and military deserters, especially those whose surrender had already been formally requested. Similarly, the above-mentioned categories of fugitives could not "be assisted to move to more distant places in order to avoid surrender." Moreover, both parties to the agreement undertook to inform and guide each other on how to search for fugitives. Officials or civilians providing assistance to fugitives were subject to local/national criminal laws.

The 1844 agreement strictly prohibited the subjects of both countries from purchasing goods bearing the hallmarks of "government property." The purchase of goods which bore an "undeniable hallmark of government property" was forbidden regardless of whether they were purchased from a person who: a) had not been declared a fugitive; b) did not have an outstanding warrant issued in his name; c) or from an ordinary subject. The main purpose of this prohibition was to block the further sale of horses abducted by fugitives. Another aim was to strictly forbid the purchase of things taken "in flight by a criminal $[. .$.$] of which$ he happens to be the unlawful owner." In 1844, both the Prussian and Russian governments (as well as the Kingdom of Poland) guaranteed the use of all means available to them under law currently in force with a view to the mutual handing 
over of military objects and "utensilia" found on captured fugitives, especially horses, "without compensation of any kind."

The act of 20 May 1844 even envisaged the hypothetical situation of the voluntary return of a fugitive (i.e. of a "non-surrendered" civilian fugitive, deserter or criminal offender) to his original territory. In the absence of any obligation to apprehend such individuals (the conditions of the cartel convention made no provisions in this regard) and as a result of the spontaneous return of such a fugitive, who having escaped again returned to the country to which he should once have been surrendered, the authorities of the latter country were no longer obliged to prosecute or surrender him.

Article 23 of the agreement was of great importance, as it specified the obligation of both states to take back into their territory those of their nationals "whom the other state wishes to rid itself of when they become a burden to it for whatever reason." However, this obligation was no longer valid when the person the authorities wished to send back to their country of origin (as a persona non grata) had already been abroad for at least ten years without a valid passport or what was known as a certificate of origin (Heimatschein) issued by the competent authorities of their home country, or when ten years had elapsed after the return date stated in the passport or certificate of origin.

Persons who, at a given moment, held valid passports, certificates of origin or other "legitimation" documents, or documents whose validity had expired at the latest in the preceding 365 days (if they were not subjects of Prussia, the Russian Empire $^{27}$ or the Kingdom of Poland) could be sent back to the issuing states without any preliminary or prior correspondence on the matter. The specification of the transfer ("handing over and receipt") of such persons by Prussia and Russia was as follows: on the Russian side, the procedure was such that special commissioners were appointed, who were obliged to serve on the borders of the Empire and of the Kingdom of Poland and, as mentioned above, "watch over the maintenance of good neighbourly relations [with Prussia]." On the Prussian side, in turn, this task was assigned to provincial councillors located in the border counties.

Apart from the cases described above, all persons claiming to be subjects of the parties to the cartel convention could be sent back from one of these countries to the other only by previous agreement between Russian, Polish and Prussian officials; and this only if the subjectivity of the person as belonging to the country to which he was to be deported was proved beyond any doubt. The costs generated by the process of returning such an individual to the other country were attributed to the state that "will complete the return of the person."

Should the Russian or Polish authorities wish to deport someone whose had to pass through Prussian territory on the way back to his home country, the Berlin government (in accordance with Article 23 of the cartel convention of 1844)

27 Gazeta Rządowa Królestwa Polskiego, 167 (16/28 July 1844), p. 1199. 
always had to grant its consent for such a "transit" to be made through its territory. This deportation transit was, of course, subject to certain rules, which had to be complied with in order for it to be carried out properly. When a deportee was handed over to a third country, the Prussian border administration had to be provided with: a) a certified letter of admission from the authorities of the country to which the deportee legally belonged, and b) a fund to cover the deportee's travel and subsistence expenses for the entire journey up to the border of the country of his destination or the home country. In the absence of full compliance with these two conditions, the Prussian authorities, in view of the treaties signed in this respect between Berlin and other countries, did not feel inclined to accept persons whose final destination would be a third country. Under these circumstances, i.e. after allowing third-country nationals to cross the Polish or Russian border (on the basis of a passport issued by the administration of the Russian Empire or the Kingdom of Poland), and after preventing them from entering their presumed home country, the Prussian authorities reserved the right to send such individuals back to Russia or the Kingdom of Poland within a year of entering Prussia. The passports of the persons to be sent back had to contain a precise description of the reasons for the decision.

It is worth noting that the ratification of the whole content of the convention by Tsar Nicholas I after thorough (in the original: "sufficient") analysis was signed by the Russian monarch, "who vouched with the imperial word" for himself and his successors. Nicholas also promised to unalterably preserve and see to "everything" that the said convention contained. ${ }^{28}$

Among the provisions of the renewed cartel agreement between Russia and Prussia, the following are particularly noteworthy: a) the procedure for the bilateral 50-50 payment of the costs of the forced stay of a captured deserter, and b) the establishment of permanent commissioners to deal with border disputes.

\section{The convention concerning the mutual surrender of deserters and fugitives concluded between Tsar Alexander II and King Frederick William IV of Prussia on 27 July / 8 August 1857}

In the record of the cartel convention between Russia and Prussia of 27 July / 8 August 1857, we find in the introduction the information about the mutual consent of both monarchs to its signing by their plenipotentiaries drafting this legal act. ${ }^{29}$ In the preamble to the agreement of August 1857 we also find an explanation

${ }^{28}$ Gazeta Rzadowa Królestwa Polskiego, 167 (16/28 July 1844), p. 1200.

${ }^{29}$ Polnoye sobranje zakonov Rosijskoj Imperii, Sobranje Vtoroje, vol. XXXII, Otdelenje Piervoje, Sankt Peterburg, 1858, p. 778. 
of the basic reason for its signing, which was the expiry of the twelve-year period of validity of a similar, previously concluded Prussian-Russian convention on mutual extradition of fugitives of 8/20 May 1844 (described above) as well as the need to "supplement and define more clearly" at least some of its articles. Hence, from the point of view of both the Prussian and Russian monarchs (literally in the document: the Russian Emperor and the Polish King) it was considered "necessary" and "useful" to conclude a new convention on the extradition of fugitives. As it became clear from the further part of this preamble, for this purpose, the Russian side delegated as a competent person for further negotiations in this matter the then secret counsellor Baron Philipp Brunnow, ${ }^{30}$ acting at that time as the extraordinary plenipotentiary envoy and plenipotentiary minister at the courts of the Prussian king and of Mecklenburg-Schwerin and Mecklenburg-Strelitz. He was the holder of: a) Russian orders: a first-class St. Vladimir; St. Alexander Nevsky with diamond decorations; a first-class White Eagle (!), a first-class St. Anne and a first-class St. Stanislaus, and b) Prussian orders: a first-class Red Eagle and a firstclass St. John of Jerusalem, among others. The Prussian side was represented in these negotiations by Baron Otto Theodor Manteuffel, ${ }^{31}$ Chairman of the Royal Council and Minister of Foreign Affairs. He was, among others: a) a Knight of the Prussian Order of the Black Eagle and Red Eagle, decorated with oak leaves, crown and sceptre, b) a Grand Commander of the Hohenzollern Order; c) a Commander of the Order of St John; d) a Knight of the Tsarist Order of St Andrew and e) a Knight of the Russian Order of St Alexander Nevsky. The two plenipotentiaries, having exchanged their letters of credence, finally concluded and signed another Prussian-Russian convention on fugitives in 1857. ${ }^{32}$ Taking into its remit the Russian Empire, the Kingdom of Prussia and the Kingdom of Poland, it was signed for (another) twelve years.

Tsar Alexander II ratified this convention at Peterhof on 9/21 August 1857. He remarked at the time, "promising in our imperial word, to us, our heirs and successors, that everything in this convention, which has been decided, observed and executed, will be inviolable." 33

In accordance with Article 1 of the Convention, its provisions entered into force four weeks after the exchange of ratified documents, applying to a number of persons. Firstly, it covered all persons who, while on active military service, would escape from one army or the other (and all army property or items of "military equipment" taken by the aforementioned fugitives). These "utensilia,"

30 "Brunov baron, zatem graf Filipp Ivanovicz," in: Rosskij bibliograficzeskij Slovar: Betankur - Bjakster, Izdatelstvo pod naliudenjem predsedatelja imperatorskogo Russkogo Istoriczeskogo obszczestva, vol. 3, Sankt Peterburg, 1908, pp. 371-384, 699.

${ }^{31}$ K.Wippermann, "Manteuffel, Otto Freiherr von," in: Allgemeine Deutsche Biographie, vol. 20, Leipzig, 1884, pp. 260-272.

32 Polnoje sobranje, pp. 778-779.

${ }^{33}$ Ibid., p. 788. 
besides horses, included especially harness, weapons and ammunition. Secondly, the cartel agreement of 8 August 1857 applied to all persons who were part of the so-called "reserve" (i.e. already exempted from compulsory military service, but liable to rejoin the army on a formal summons). Thirdly, the new law in principle covered all persons who under the law of the country they had left (whether intending to return or not) were obliged (at least on their return) to perform military service. Fourthly, the provisions of the new cartel convention applied to all persons who, having committed a crime or an offence in one of the two parties to the agreement, fled to the other country "to hide from justice" and had to be surrendered in order to be duly punished.

In case when the fugitives (deserters) were caught in uniforms, or if any military equipment or "utensilia" were found on them, or if there was no doubt that they had escaped "from the service" in the other country party to the agreement, then such persons were to be immediately arrested (even without a prior request from the affected country) and transported with all their military equipment to the border in order to be handed over to the military or other officials designated to receive them.

As for persons about whom it was not absolutely certain that they were fugitives, but on the basis of the investigation, or due to special circumstances, they could be considered such fugitives, the competent military or civilian superiors, after becoming acquainted with the place(s) of temporary residence of such a person, were obliged to immediately take the necessary steps to prevent their further escape. Then it was necessary to interrogate such a suspect, and draw up a protocol from this "verbal examination" which was then to be passed on to the military authorities of the other party to the agreement. Then, the other side announced whether the suspect in question had escaped. As a result of such a statement, if it turned out that the caught individual had deserted, he had to be released as a military fugitive.

The detention and surrender of persons that were obliged to perform military service (i.e. potential recruits, etc.) had to be carried out in no other way than in accordance with the specific requirements which, in each particular case, were imposed on the authorities of the state to which these persons formally belonged. However, certain limitations were introduced. In the first place, no person formally liable for extradition under Article 1 of the agreement could be surrendered to the other party if they held the nationality of the state to which they entered before entering the state from which they had recently withdrawn, or before entering the service of that state. In this case, however, the horses and military equipment taken by these persons during their escape had to be returned. Secondly, if a deserter (or a person liable to perform military service) had committed a crime or an offence in the territory of the state to which he had escaped, his extradition could also be refused, at least until he had served his sentence, in accordance with the law of the state on the territory of which the crime or offence had 
taken place. Thirdly, if at least two years had elapsed since the escape made for the purpose of avoiding military service by persons who would formally be liable to investigation concerning extradition (i.e. as deserters or individuals who could be considered fugitives), then the state that received a request for the surrender of such persons was not obliged to grant it. If, however, a person in hiding from military service (or a deserter) had committed a crime or an offence before their escape (or had merely been charged with such a crime), they would be extradited nevertheless, even if more than two years had passed since their escape to the other state. ${ }^{34}$

Article 4 of the convention specified that the proceedings in the case of fugitives and deserters were to be conducted on the part of Russia and the Kingdom of Poland by "the general closest to the Prussian border" (this probably meant the governor-general residing in the Empire or the gubernial military chief residing in the Kingdom of Poland). On the Prussian side, this issue was to be handled by: a) the provincial governor and b) provincial officials delegated to hand over the deserters. Fugitives (persons hiding from conscription), on the other hand, were to be pursued by the authorities of the Russian Empire and the Kingdom of Poland through direct contacts with the local Prussian provincial office, while on the Prussian side such investigations required contact with the nearest Russian and Polish military and civil administrative authorities. On the Russian side, a special commissioner was assigned, as was the case previously in 1844, to carry out the task of maintaining good relations with Prussia in terms of surrender of deserters and fugitives and ensure "good neighbourly relations on the border."

In the event that a given deserter, before escaping from the service of a party to the convention, had escaped from the army of another sovereign monarch, or of a state with which one of the contracting parties had signed a convention on the surrender of fugitives, such a fugitive would be "returned" to the last army from which he had escaped.

Article 6 of the convention specifically prohibited the authorities of either state (i.e. of either party) from accepting fugitives into the military or civilian service of the other state. This prohibition applied, in the first place, to those about whom it was certain or at least plausible that they were fugitives from the other state. It was also forbidden to let through the border any non-commissioned officers or soldiers belonging to the army of the other sovereign party, unless they could produce a passport ${ }^{35}$ or a certificate issued in writing by the chief or commander of the army unit to which they belonged.

All members of the military who a) could not produce a passport or a letter of attestation of any kind, and about whom the authorities had obtained "appropriate reports" either on their own or through the knowledge of their subordinates, and

\footnotetext{
34 Ibid.,. 779-780.

35 Ibid., p. 780.
} 
who b) for whatever reason gave cause for suspicion as to the legality of their stay, were to be detained by the military or civilian officials of the contracting parties. Such individuals had to be arrested immediately; in addition, all objects found on them or being in their possession were also to be seized.

Both parties to the convention undertook to adopt such legal and procedural arrangements in their respective countries that would make it possible to verify permanently and without delay all extradition requests submitted "in good faith" by the state authorities designated for that purpose. Moreover, even if it turned out that the persons named in the extradition request had already joined the service of the state in which they were at a given moment, this situation did not abrogate the mutual promise of extradition. For all that, the appearance of doubt "as to the truth of any of the circumstances relied upon," save in exceptional circumstances, could not serve as a pretext for refusing extradition.

As was evident from the experience of previous years, if the person being handed over belonged to the category of individuals who were to be handed over in an almost automatic manner (i.e. even without a formal request from the other party), when such a deserter or any person evading military service was handed over, it was strictly mandatory to provide a protocol describing the reasons and circumstances of his detention. Such reports were immediately sent back to the "injured party" together with the (military) "utensilia" that served the fugitive during the escape. If, on the contrary, the deserter in question belonged to the category of persons who were extraditable only after a prior exchange of information between two military superiors (possibly also on special request), in order to avoid any doubt as to the conformity of his extradition with the provisions of the Convention of 27 July / 8 August 1857, the documentation of the case on the basis of which the extradition was decided was always to be presented in the original or in the form of a certified copy.

According to Article 10 of the new Russian-Prussian extradition convention, the border stations already designated for the permanent extradition of deserters and other persons were to remain unchanged at least until the two superiors of the relevant services jointly agreed to change them. It was a task assigned to the local military or civilian authorities, depending on their military or civilian rank, to designate specific officials for these exchange stations who were to receive the persons to be extradited in person; they were also expected to liaise on the matter with the appropriate officials of the other party.

The daily subsistence costs of a deserter arrested, or of any person captured who was liable to military service, were calculated at twelve Russian silver kopecks, or four Prussian silver groschen, from the day of arrest until the moment of extradition, carried out either at the request of the other party or, as it were, spontaneously. If the deserter brought with him across the border a horse belonging to the state, it was the duty of the detaining party to provide the animal with two pots of oats (“два метца овса") and eight pounds of hay per day, together with 
the necessary straw. Payment for fodder expenses had to be made at the price of purchase current in the nearest town from the transit point.

The second part of Article 11 of the convention clearly indicated that the deserter had to be handed over no later than eight days from the moment of his apprehension, which in turn, according to the rules, had to take place as soon as the place where the prisoner was hiding was identified. Both parties to the convention were to calculate this eight-day detention period in the same way, ${ }^{36}$ unless his handover had to be delayed beyond the specified time of eight days because of the considerable remoteness of the place where the deserter was detained, or because of other clearly "unfavourable" circumstances. If the deserter was admitted to hospital on account of illness, the authorities of the other state demanding his surrender (and release from hospital) paid fifteen Russian kopecks in silver or five Prussian silver groschen a day for the time such an individual remained in hospital.

In the case of returning a horse taken by a fugitive to the state to which it originally belonged, the person who captured the animal was to receive six roubles seventy-five kopecks in silver (which equalled the amount of seven and a half Prussian thalers) as a reward from the state to which the animal was handed over.

In order for this reward (and the costs of the detainees' maintenance) to be paid as soon as possible, and the animals brought in returned (these sums could not, under any pretence, be increased afterwards), the two contracting parties were to assign special officials engaged in receiving fugitives at exchange stations and exchanging appropriate sums (capitals) of money. It was from this money that they could pay the sums due for the maintenance of the deserter, or of the fugitive person liable to military service, or for the fodder and stabling of the horse. In this way, bills presented by the officials in charge of extradition from the territory of the capturing state were paid; this also applied to prizes awarded for the capture of a fugitive or of his horse.

If the entries of the amounts submitted for payment were found to be erroneous, then the sum entered in such account had to be paid in full nevertheless. This was followed, of course, by consideration of objections. The only exceptions to this rule were limited to such cases where either a) the order on simultaneous handing over of the person and the military equipment of the deserter was not fulfilled or b) the demand for the handover of that equipment was not made in the form of a formal summons or its certified copy. In such cases, funds intended to cover the costs of the fugitive's sustenance and the rewards could not be issued.

According to Article 14 of the 1857 convention, just as deserters and fugitives in military service could not, in the country of their refuge, incur debts to which the government of the state to which they formally belonged would be legally liable, so also in no case could such debts, at the time of the extradition of the fugitives, be taken into account in any proceedings between the authorities of

${ }^{36}$ Ibid., p. 781. 
the parties to the convention. Moreover, if any such extraditable person, during his stay in the state which had extradited him, had acquired obligations to private persons (which, by reason of his extradition, he could not meet), then the injured party retained only the right to refer the question to the competent chief officer of the authorities of that state to which the debtor formally belonged. Similarly, if a deserter or a person subject to military service at the time when the request for his surrender was made was under guard, at the request of the people with whom he had contracted obligations, because of non-payment of debts, even then the government to which the request for deportation was made could not be relieved of its obligation to surrender him immediately.

If any fugitive in the power of either party to the convention had committed a crime or offence (or was merely suspected of having done so), and had subsequently escaped and was in the territory of the other sovereign, there was then in force an order for the mutual surrender of all such offenders or suspects. This power remained unchallenged, irrespective of the official rank or social condition of the guilty, accused, or suspected individual; such persons were therefore extraditable, whether they came from the nobility, the bourgeoisie, or the peasantry; whether they were free persons, bound by the laws of serfdom, or members of military or civil institutions. When, however, it appeared that the "criminal or accused" was a subject of that sovereign into whose territory he had effectively fled after committing a crime or offence in the lands of the other party, then in such a case he was not extradited. On the other hand, the sovereign to whom such a criminal or accused was subject had to make sure that he be brought immediately to trial in accordance with the laws of his state. ${ }^{37}$

In addition, Article 16 of the convention in particular provided that if a person, having moved from one state to another, committed a crime or offence there and then returned to the state from which he had originally come, the authorities of the receiving state (even though the transfer of such a person could not be based on the provisions previously mentioned in the convention under consideration) had to assist, by every available means, at the request of the competent authorities of the state where the offence had been committed, in investigating the events and "discovering the perpetrators." Such action could only take place if the committed crime or offence was punishable under the law of the state requested to take action.

However, if a person was arrested in the state where he had committed a crime, the sovereign in whose territory the guilty or suspected individual had been arrested could order that he be tried and punished by a national court. Under no circumstances could a person detained in the same state where he was found guilty of a crime or offence be handed over and taken into custody by the other state, at least until a formal penalty was pronounced.

${ }^{37}$ Ibid., pp. 782-783. 
The apprehension of a culprit who was to be extradited from one state to another had to be ordered by a police authority or a court of the state in which the individual had committed the crime, and the request had logically to be made to a police authority or a court of the other state. In addition, the right to lodge such claims was held by: a) in the Russian Empire - a special commissioner, whose task was to supervise the observance of the "principle of good neighbourly relations"; b) in the Kingdom of Poland - the "chief official of the border districts," who by definition had the same rights as the Russian special commissioner; c) in Prussia - the royal prosecutor. The authorities concerned, even if they had no right to comply with a request for the surrender of a given fugitive, were obliged to accept such a request and to forward it without delay to the appropriate officials.

However, the actual extradition on the part of Russia and the Kingdom of Poland could take place in no other way than at the request of the principal court of that Prussian province where the offender or the accused had (or should have) already been the subject of judicial investigation. Such a request was to be addressed to the governor-general of the governorate of the Russian Empire, or to the principal court of that governorate of the Kingdom of Poland where the offender or suspect was hiding. ${ }^{38}$

On the Prussian side, on the other hand, extradition could be carried out at the request of the governor-general or the civil governor of the governorate of the Russian Empire (or at the request of the principal court of the governorate of the Kingdom of Poland) where the offender or the accused had (or should have) already been under judicial investigation. In the aforementioned cases it was necessary to apply to the principal court of that Prussian province where it was presumed that the offender or the accused was in hiding (regardless of whether he was employed in the public service, of course). The Russian authorities were obliged to inform the Prussians of their extradition request through a special Russian commissioner.

At the same time, the two governments were obliged to inform each other of any changes in the location and powers of the various principal courts and government authorities that at any given time were responsible for the execution of extradition requests.

In all the above cases, whether the extradition request was made to a governor-general or a civil governor of the Russian Empire, or to the principal court or the civil governor of a governorate of the Kingdom of Poland, or to any of the principal courts in the Prussian provinces, it was absolutely required that such an application should be accompanied by a copy of: (a) a court judgment (if one had already been issued); or (b) a writ of summons to be brought before a court; or (c) a detention order (Haftbefehl) issued by a competent court that specified the "tiniest details" of the offence or misdemeanour, or, alternatively, the reasons for suspecting that such had been committed. In the case of theft of public funds

38 Ibid., p. 783. 
or property belonging to the state treasury, the (civil) governor's application had to be accompanied by verifiable information about the stolen funds or property. The same formalities had to be observed in the execution of an extradition request issued by the supreme court of the Kingdom of Prussia.

A request for the extradition of an offender or accused, and for the release of documents "attributed" to him, had to be presented to the relevant court or official within six months. In case of delay, the obligation to extradite the offender or the accused ceased.

The surrender of the fugitive could take place if after the interrogation of the accused person it was found that (a) he was indeed the wanted person and that (b) the act with which he was charged was of the same kind for which, under the law of the state which requested his extradition, he would be subjected to criminal investigation. If the person whose extradition was sought was charged with more than one crime or offence, he had to be extradited even if only one of the acts attributed to him was subject to criminal investigation under the law of the state requesting his extradition. The expelled offender was taken to a place where the representatives of the authorities requesting the surrender of the person concerned were present. However, he was handed over to the other party only upon payment of his living expenses.

Article 17 of the Russian-Prussian convention of 1857 precisely specified the amount of these fees. Thus, the cost of keeping a caught criminal, calculated directly from the day of his arrest, was calculated at twelve Russian silver kopecks, or alternatively at four Prussian silver groschen a day. For the costs of keeping the criminal "under guard," meanwhile, it was mandatory to pay fifteen Russian silver kopecks or five Prussian silver groschen a day. In addition, the amounts owed in each individual case for transporting the deserter or fugitive to the border and for providing him with the necessary clothing were also to be paid.

Like in the previous cartel convention, also in that of 1857 neither deserters nor fugitives liable to military service (at a time when they resided in the country of their destination) could be subjected to any persecution or prosecution by the services of the other party to the convention, regardless of whether such persecution or prosecution had been attempted openly or secretly. Hence, any military or civil authority, any detachment or any other person sent to capture a fugitive, whether openly or secretly, could not cross the Russian-Prussian border. If, therefore, in order to capture one or more deserters, criminals or fugitives liable to military service, a military or civilian detachment was sent from the party concerned, or if any other measure to capture a fugitive was implemented, then such actions could not take place across the border. The detachment in question had to stop at the border, and the national frontier could only be crossed by a single person who, moreover, was not permitted to resort to any act of violence against the fugitive. However, the delegate could understandably apply to the local military or civilian authorities of the receiving state for the surrender of the fugitive(s), 
submitting a written request to that effect. As a rule, such a messenger had to be received with the respect that the principle of good neighbourly relations between Prussia and Russia demanded, according to the rules of the cartel convention. ${ }^{39}$

Moreover, any action taken by military or civilian officers of one party to the convention on the territory of the other state without the appropriate formal consent was considered a border violation, and the person guilty of this insubordination was subject to severe punishment. If doubts arose as to whether the state border had in fact been crossed, or whether border regulations had been breached in any other way during the pursuit, a special joint (i.e. Russian-Prussian) commission of inquiry was to be set up to investigate the matter, chaired by a commissioner who was obliged to lodge a complaint in such a case. The appointees to such a commission were: a) on the part of Russia - a special commissioner on whom was imposed the duty to solve any problems related to the preservation of "good neighbourly relations"; b) on the part of the Kingdom of Poland - the head of the nearest border district; c) on the part of the Kingdom of Prussia - the provincial councillor (Landrat) of the district where the alleged breach of the border had occurred. In addition, on the part of Prussia, the public prosecutor of the judicial district (Oberstaatsanwalt des Obergerichtsbezirkes) or the public prosecutor of the border district where the border violation took place also gained the right to be present at the joint commission investigating the event. Under these circumstances, a special official appointed by the imperial government or the administration of the Kingdom of Poland also had to be present during the investigation. In all cases, of course, the number of members of the joint commission was the same "on the side of each of the contracting parties." In special circumstances, both governments could order that these investigations be entrusted to officials who were specifically delegated for this purpose.

In some cases, the commissioners had the power to summon a judicial officer to examine witnesses and take oaths from them. If lower level military officials or members of the border guards were involved in the case under investigation, they were also asked to appear before the commission in the presence of the person(s) sent by the military authorities concerned for the purpose.

The bilateral reciprocal commission was obliged to follow procedures designed to gain reliable knowledge as to whether the border had been breached and, if so, who was responsible for the breach. If there was no disagreement, the committee would submit the whole file to the court of the country to which the accused belonged in order to make a ruling and immediately inform the authorities of the country whose border had been breached.

Any border violator apprehended in the country whose border had been crossed ${ }^{40}$ was sent to the nearest military or civilian court, depending on whether

\footnotetext{
39 Ibid., pp. 784-785.

40 Ibid., p. 785 .
} 
the culprit was a member of the army or civil authorities. The appointed court reviewed the indictment and, after hearing witnesses, brought the case to a point where a verdict could be passed. The record of the entire case was then forwarded either to the commander-in-chief of the troops to which the culprit belonged, or (if such a defendant was a civilian) to the appropriate superior of his office for an opinion or adjudication in accordance with the laws of each state. Investigations had to be conducted without unnecessary interruptions and as quickly as possible. If the court designated for sentencing requested additional explanations in advance, this information was provided to the satisfaction of the said court by the commissioners conducting the original investigation.

To all the authorities and subjects of the two monarchs interested in the practical implementation of the convention, Article 20 of the new extradition treaty of 1857 strictly forbade the harbouring of: a) deserters; b) fugitives liable to perform military service; c) individuals in respect of whom a request for extradition had already been made and d) criminals who were already scheduled for deportation. It was also, of course, forbidden to facilitate in any way whatsoever the escape of these persons to a place other than their previous residence, which would have the effect of hindering, or preventing, their final surrender. Those subjects who committed such offences were to be dealt with by both governments (i.e. Prussian and Russian) in accordance with the local legal norms of their respective countries, and the authorities of the parties to the convention - with a view to mutually authenticating their actions - were obliged to inform each other of the legal and factual steps taken in order to find such offenders as well as of the penalties imposed on them.

As in the previous convention, Prussian and Russian subjects were especially strictly forbidden to buy any objects whose provenance "evidently" indicated that they were (stolen) state property. This prohibition applied even if the seller of the items in question was not formally recognized as a deserter at the time, nor was he wanted as such. The prohibition on the purchase of "treasury-owned" horses, taken across the border by deserters, or of any objects which had been brought with them by fugitives when they fled abroad (and which had thus come into their possession illegally) was particularly emphasised. Both governments undertook to use all means practicable under local law to return to the other party items of state-related or official provenance taken by the deserter or fugitive in question. Such objects were mutually returned without any reward or customary remuneration.

If a deserter, or any other person fleeing abroad who was subject to conscription, or other offenders generally falling into such a category, was nevertheless not extradited and not surrendered, and if (in such cases) he was nonetheless finally extradited on the basis of the convention of 1857, but in the meantime (by means of another escape) found himself again in the territory of the state to which he had previously had to be deported, then the sovereign of that territory was obviously not obliged to surrender him. 
Each of the two parties to the convention undertook to readmit those of its nationals from whom the other state wished to "relieve" itself. This obligation ended, however, if at least ten years had elapsed since the person to be repatriated had left his home country. In addition, the non-return of a person had to be based on the fact that he had previously lived in a foreign land without a valid passport issued by the relevant authorities or a formal certificate of origin (Heimatsschein) or that his passport or certificate of origin had expired at least ten years previously. This ten-year period was not considered to be subject to interruption due to the individual's confinement to prison or arrest in the country from which he was being deported. To the number of years of (illegal) residence after which the obligation to readmit a particular fugitive expired included the period of detention of the person concerned "under guard." This obligation to take back one's former subject expired for the country of origin ("ipso facto") if during the period of this detention "under guard" in the other country ten years had elapsed since his leaving the homeland.

If a person who had been convicted or arrested was sent back to his home country before the expiry of the above ten-year period and had not fully served his sentence, he could be legally obliged to serve the remainder of the sentence in his home country, although this sentence could be modified depending on the circumstances and in accordance with the applicable local law. On the other hand, persons whose passports, temporary certificates of origin or other similar documents were still valid, or had expired only recently (i.e. up to one year from the time in question), could be expelled (if they were subjects of one of the two parties to the convention) to Russia (and the Kingdom of Poland) and Prussia without any prior correspondence with the competent authorities of the state concerned. ${ }^{41}$

The surrender and reception of the aforementioned persons could take place: a) on the part of Russia and the Kingdom of Poland (depending on the circumstances) - by representatives of the military authorities at the places strictly specified for the extradition of deserters and other persons (i.e. in accordance with the contents of Article 10 of the convention) or through customs or similar authorities; (b) on the part of Prussia - through the provincial councillors of the respective border districts.

With the exception of a few cases (described in the fourth paragraph of Article 23 of the 1857 convention), no person claiming to be a subject of one of the parties could be "transported" into the territory of the other country, except by means of an agreement to that effect concluded bilaterally between the appropriate authorities. On behalf of Russia and the Kingdom of Poland such agreements could be concluded by a special Russian commissioner or the chief official of the given border district on the border with the Kingdom of Poland. On the part of Prussia such powers were usually in the hands of the provincial councillor (Landrat) of

${ }^{41}$ Ibid., pp. 786-787. 
the border district. As soon as it was established, on the basis of unequivocal evidence, that the person subject to extradition was actually a subject of the state to which he was to be transported, he was to be immediately handed over to the other state and this without specifying his "religion or origin" (Heimat). This was also done when the place of birth and the social rank to which such an extradited individual belonged could not be established with certainty.

As in the previous convention, the question of extradition to a third country was resolved. Namely, when the governments: a) of Russia or b) of the Kingdom of Poland wished to extradite a person who could not be transferred to his homeland otherwise than through the Prussian territory, the Berlin authorities could never refuse their consent to such a transfer. But in order to effect such a long-distance extradition it was necessary, at the time of the surrender of such an individual to the Prussian border authorities, to submit (a) a certified statement from the government under whose authority the person was originally placed, consenting to his readmission; (b) an adequate sum of money, covering the full anticipated cost of transporting and handling the person to be extradited to a third country. In the absence or only incomplete fulfilment of these two conditions, the Prussian government - having in any case regard to the provisions of the extradition convention of 1857 concluded between Prussia and Russia - was not in a position to receive persons who were to be sent on beyond its territory.

If persons belonging to such a third country, subjected to extradition from the Russian Empire or the Kingdom of Poland, were to enter Prussia on a Russian or Polish passport, and the government of the country, which was considered their homeland, ultimately refused to accept them, then the Prussian authorities retained the right to send such persons back to Russia or the Kingdom of Poland. However, this possibility existed only for a period of one year ${ }^{42}$ from the date of their original admission to Prussia. The Prussians were then obliged to write an appropriate note in the passport of the returned person.

If, however, a foreigner who had voluntarily left Russia or the Kingdom of Poland, or who had been expelled from these territories without a precise designation in the Kingdom of Prussia of any place to which he would be sent, finally reappeared in Prussia as a result of the refusal of the state which he considered his fatherland, then the fact that such a person held a Russian or Polish passport could not serve as a basis for transferring him back to the borders of the Russian Empire or the Kingdom of Poland. Therefore, neither the Russian nor the Polish authorities were obliged to readmit such a person. ${ }^{43}$

As can be seen from the above, the Russian-Prussian cartel convention of 27 July / 8 August 1857, being in large part a recapitulation of previous bilateral arrangements, in principle only completed the numerous legal provisions on

\footnotetext{
${ }^{42}$ Ibid., p. 787.

${ }^{43}$ Ibid., p. 788.
} 
this issue in a number of details. It was the last attempt by the legislatures of the Russian Empire and the Kingdom of Prussia in the 1850s to detail the arrangements for the return of deserters, fugitives and criminals.

\section{Conclusion}

With a relatively fixed set of issues raised in the content of the two RussianPrussian cartel conventions of the 1840s and 1850s, where the respective issues were discussed in greater or lesser detail, usually only with minor changes to the individual concrete provisions and even more rarely with the addition of new hitherto untouched issues, it is here that the problem of the mutual exchange of opinions (and general correspondence) regarding persons suspected of having absconded from military service and otherwise deserves our special attention. Similarly, a kind of preventive punishment (as a result of receiving reports on an "alleged" illegal crossing of the border) deserves our close attention, especially as this procedure obviously had to apply only to persons "caught with the intention" of unauthorised crossing of the border line. Another important tendency seems to have been the emphasis on the importance of the continuous transcription of the interrogations of deserters and fugitives, also for the purpose of submitting them to the other party to the convention. As can be seen from an analysis of the content of these two agreements, great importance was also attached to, among other things: a) the strict regulation of financial matters; b) the establishment of permanent commissioners for the regulation of disputes and the maintenance of "good neighbourly relations"; c) the limitation of time for the prosecution of desertion or escape; as well as to $\mathrm{d}$ ) the procedure for transporting the deserter to a third country.

In conclusion, it can be generally said that the extradition treaties between Tsarist Russia (the Kingdom of Poland) and Prussia signed in the 1840s and 1850s despite their well-thought-out detail, covering practically all issues related to extradition (and a specific measure of their practical verifiability was undoubtedly the fact that they were substantially reiterated in 1844 and 1857) - were characterised by absence of formally political aspects. It is true that there are some passages in the extradition clauses referring to the possibility of getting rid of undesirables, or more precisely of individuals whom a given state "would like to get rid itself of," but this is far from being an overt reference to strictly political issues.

It seems that this state of affairs, which we must admit was quite characteristic of the conditions in which the administration of the partitioning states functioned on Polish soil, can be partially explained by the desire to avoid a negative reception of such provisions on the part of the Western powers. However, it would be more pragmatic, at least in my opinion, to pay attention to the provisions of an earlier secret protocol (an addition to the Russian-Prussian cartel convention) 
of March 1830, in which both partitioning states promised each other help and support in prosecuting "criminals" of a political nature who fled across the border. In spite of the fact that this last cartel convention from the period before the November Uprising formally lasted only twelve years, and that the secret protocol attached to had the force of law for the same period, both partitioning states apparently recognized its practical validity during the entire Paskevich epoch and soon after its end. Thus, it seems possible to conclude that the RussianPrussian extradition policy for the 1840s and 1850s was, at least in its most important dimensions, a continuation of solutions that had already been taken earlier, i.e. before 1831 .

\section{Abstract}

As early as in 1832, dedicated facilities for the exchange of fugitives (which had not been in operation during the Polish-Russian War of 1831) were re-established in the Kingdom of Poland, including, of course, on the Prussian border. In the spring of 1832, Field Marshal Paskevich ordered that a special "instruction for officers charged with the exchange of fugitives at border post stations" be drawn up and implemented. After the termination of the Russian-Prussian cartel convention of 17/29 March 1830, a new extradition treaty was concluded between the two countries on 8/20 May 1844. Later still, another Russian-Prussian cartel agreement was signed on 27 July / 8 August 1857 . Both treaties strongly emphasise such issues as the limitations for prosecuting desertion or escape, the procedures for having deserters transported to a third country and, finally, the establishment of standing commissioners whose task was to resolve contentious issues and maintain "good neighbourly relations". It appears that the Russian-Prussian extradition treaties of the 1840s and 1850s - despite the provisions concerning expulsion of "undesirable" persons - were free from overt political references.

\section{Bibliography}

Central Archives of Historical Records in Warsaw (AGAD), Zespół II Rady Stanu Królestwa Polskiego 1833-1841, call no. 102, 103, 104, 105.

"Bar. Meyendorff Pietr Kazimirowitch," in: Spisok grazdanskim chinam piervych III klassov, Ispr po 1-je jnv. 1863 2., Sankt-Petersburg, [1863], pp. 29-30; https://vivaldi.nlr.ru/ab000000479/ view/?\#page $=49$ (accessed: 23 December 2020).

Blakesle, Ch.L., "The Practice of Extradition from Antiquity to Modern France and the United States: A Brief History," Boston College International and Comparative Law Review, 4/1 (1981), pp. 39-60.

"Brunov baron, zatem graf Filipp Ivanovicz," in: Rosskij bibliograficzeskij Slovar: Betankur Bjakster, Izdatelstvo pod naliudenjem predsedatelja imperatorskogo Russkogo Istoriczeskogo obszczestva, vol. 3, Sankt Peterburg, 1908, pp. 371-384, 699.

Dziennik Urzędowy Województwa Mazowieckiego, 37 (4 June 1832).

Epps, V.C., "The Development of the Conceptual Frame Work Supporting International Extradition," Loyola of Los Angeles International and Comparative Law Review 25/3 (2003), pp. 369-388.

Gazeta Rządowa Królestwa Polskiego, 166 (15/27 July 1844).

Gazeta Rządowa Królestwa Polskiego, 167 (16/28 July 1844). 
Latawiec, K., Rosyjska straż graniczna w Królestwie Polskim w latach 1851-1914, Lublin, 2014. Magnuson, W., “The Domestic Politics of International Extradition," Virginia Journal of International Law, 52 (2012), pp. 839-901.

Polnoje sobranje zakonov Rosijskoj Imperii. Sobranje Vtoroje, vol. XXXII, Otdelenje Piervoje, Sankt Peterburg, 1858.

"Prusso-Russian Extradition Treaties," New York Times (10 May 1863), p. 4, https://www.nytimes. com/1863/05/10/archives/prussorussian-extradition-treaties.html (accessed 4 October 2020).

Ritthaler, A., "Bülow, Heinrich Ulrich Wilhelm Freiherr von," in: Neue Deutsche Bibliographie 2, 1955, https://www.deutsche-biographie.de/sfz35397.html\#ndbcontent (accessed 17 August 2020).

Wippermann F., "Manteuffel, Otto Freiherr von," in: Allgemeine Deutsche Biographie, vol. 20, Leipzig, 1884, pp. 260-272.

Marek Rutkowski, dr hab., University of Physical Education in Kraków, ul. Jana Pawła II 78, 31-571 Kraków, Faculty of Tourism and Leisure.

(marek.rutkowski@awf.krakow.pl)

Submitted 07.10.2020, accepted 13.04.2021 